\title{
Mucosal Immune Responses and Total Carotenoid Content of Juvenile Male Guppy Fish (Poecilia Reticulata) Fed With Different Herbal Supplements
}

\section{Seyed Nesa Mousavi}

Khorramshahr Marine Science and Technology University

Hamid Mohammadiazarm ( $\sim$ azarmhamid@gmail.com )

Khorramshahr Marine Science and Technology University https://orcid.org/0000-0002-2472-4519

\section{Fatemeh Azadbakht}

Khorramshahr Marine Science and Technology University

\section{Research Article}

Keywords: Carotenoid, Guppy, Herbal additives, Immunity indices, Nutrition

Posted Date: September 7th, 2021

DOI: https://doi.org/10.21203/rs.3.rs-749941/v1

License: (c) This work is licensed under a Creative Commons Attribution 4.0 International License.

Read Full License 


\section{Abstract}

In this experiment, the influences of dietary garlic, onion, and sweet red pepper meals as herbal supplements were studied on some immunological parameters, total carotenoid content, and growth performance of male guppy fish (Poecilia reticulata) in the juvenile stage. The experimental diets were fed to fish as a control (0), and three other diets contained $20 \mathrm{~g} \mathrm{~kg}^{-1}$ garlic, or $20 \mathrm{~g} \mathrm{~kg}^{-1}$ red onion, and or $20 \mathrm{~g} \mathrm{~kg}^{-1}$ sweet red pepper powders. The male guppies with the early weight of $0.642 \mathrm{~g} \pm 0.07$ were stocked in twelve circular tanks ( $40 \mathrm{~L}$ capacity) at density of 30 fish per tank. Fish were fed to satiation the diets thrice daily. The results showed that dietary herbal additives induced a significant increase $(P<$ $0.05)$ in some mucosal immunological parameters contained alternative complement (ACH50), total immunoglobulin (Ig), lysozyme, and total protein compared to control, which were the highest in the group with $20 \mathrm{~g} \mathrm{~kg}^{-1}$ garlic powder. Also, various dietary herbal additives resulted in higher $(P<0.05)$ total carotenoids levels of lateral skin body and caudal fin of fish than control, which were the highest in the group with $20 \mathrm{~g} \mathrm{~kg}^{-1}$ sweet red pepper. The growth performance and feeding indices enhanced significantly $(P<0.05)$ in experimental groups compared to the control. As a result, used herbal supplements had beneficial effects on immunological parameters and total carotenoid content of fish. So, the highest immunity and coloration was obtained separately at $20 \mathrm{~g} \mathrm{~kg}^{-1}$ respectively with garlic and sweet red pepper meals.

\section{Introduction}

Three types of livebearers ornamental fish contained molly (Poecilia sphenops), platy (Xiphophorus maculatus), and guppy (Poecilia reticulata) from Poeciliids were cultivated by fish breeders in Iran and the entire world (Coad 2017). They have many enthusiasts because of their attractive color and easy reproduction. The past decades have seen an increase in the trade of ornamental fish, about US\$44 million annually (FAO 2019). But, the crucial points for developments in the ornamental fish industry are the improvement of coloration, immunity system, and survival rate of fish (Mohammadiazarm et al. 2021). Therefore, the commercial fish breeders try to use supplemental additives in formulated feeds for higher profits in ornamental fish trades. It seems that different herbal additives because of their metabolites have beneficial effects on the growth, coloration, reproduction, resistance to environmental stressors, and immunity system of fish (Motlagh et al. 2020). Furthermore, the herbal cost, easy access, and safe use of them are essential to select them. So, it was proved that garlic as the best additive in aquaculture feeds for increasing the growth (Ajiboye and Qari 2016, Metwally 2009), immune system (Nya and Austin 2009; Van 2015), killing pathogens (Nya and Austin 2009, Aly and Mohamed 2010, Foysal et al. 2019), motivating eating (Ajiboye and Qari 2016, Guo et al. 2015), and improving fillet quality of fish (Luo et al. 2008). Garlic (Allium sativum), as members of the family Liliaceae, contains ascorbic acid, mineral, b-carotene, and polyphenol (Mitra et al. 2012). Allicin is an oxygenated carotenoid derivative from garlic with high immunological and antioxidant activities (Wang et al. 2018). Furthermore, onion meal has been suggested as a feed attractant and promoting the growth performance of fish in aquaculture (Safari and Paolucci 2016). Onion (Allium cepa), a very 
usually used vegetable, ranks third in the world production of main herbal products (Mitra et al. 2012). It belongs to the Liliaceae family with a considerable amount of anthocyanin pigments that representing $10 \%$ of the total flavonoid content (Slimestad et al. 2007). Also, it has a high amount of calcium, potassium, and magnesium (Gabor et al. 2010) with anti-infectious (Benkeblia 2004), anticancer, and antioxidant actions (Ramos et al. 2006, Bello et al. 2012 a, Bello et al. 2012 b). Another, cheap and abundant herbal additive is red pepper from the Solanaceae family and genus Capsicum with positive effects on coloration, growth, reproductive performance, antimicrobial activities, and sensorial properties of fish fillets (Yanar et al. 2016). So, we examined the effects of three main herbal products (garlic, red onion, and sweet red pepper) in comparison with others in diet of fantail male guppy for mucosal immune responses and total carotenoid content.

\section{Materials And Methods}

\section{Experimental plan and diet production}

The isonitrogenous and isocaloric diets were formulated as control and three other experimental diets with different herbal additives. So, initially, sweet red pepper, garlic, and red onion were peel and cut into small pieces, then were dried in an oven at $30^{\circ} \mathrm{C}$ for 12 hours, and used as herbal additives with an amount of $20 \mathrm{~g} \mathrm{~kg}^{-1}$ in diets. The other ingredients of diets were prepared and purchased, and then they were mixed with herbal additives. After that, the water was added until the dough was formed. Then, the dough was pressed through a meat grinder and dried at room temperature for $24 \mathrm{~h}$. After that, the pellets were crushed and sieved for obtaining a desirable size for fish. Finally, the diets were kept at $-20{ }^{\circ} \mathrm{C}$ until use. The total protein, lipid, ash, and moisture contents of feeds were determined with the standard method (AOAC 2000, Table 1). Also, the purchased and acclimated fantail guppies with the early weight $0.642 \mathrm{~g} \pm 0.07$ were distributed in 12 circular tanks (four treatments and three replications) by volume of $40 \mathrm{~L}$ with 30 fish per tank. The fish were fed to satiation thrice daily $(08.30,12.30$, and $16.30 \mathrm{~h})$ for sixty days. The tanks were siphoned daily and oxygenated with an air blower and an air stone. The determined water temperature by a thermometer was about $28.0 \pm 1.0^{\circ} \mathrm{C}$, the dissolved oxygen by an oxygen meter was about7.5 $\pm 1.0 \mathrm{mg} \mathrm{L}^{-1}$, and the $\mathrm{pH}$ by a pH meter was about $8.0 \pm 0.2$, in the period of the experiment. Also, the photoperiod was fixed at 12D:12L. Finally, growth and feed indices were considered as follows: 
Table 1

Ingredients and proximate analysis of experimental diets ( $\mathrm{g} \mathrm{Kg}^{-1}$ dry diet).

\begin{tabular}{|lllll|}
\hline Ingredients & Control & Garlic & Red onion & Sweet red pepper \\
\hline Fish meal $^{\mathrm{a}}$ & 150.00 & 150.00 & 150.00 & 150.00 \\
\hline Squid meal $^{\mathrm{b}}$ & 250.00 & 250.00 & 250.00 & 250.00 \\
\hline Soybean meal & 285.60 & 274.80 & 279.80 & 277.40 \\
\hline Wheat flour & 18.20 & 29.10 & 24.20 & 29.30 \\
\hline Wheat bran & 150.00 & 150.00 & 150.00 & 150.00 \\
\hline Fish oil & 33.10 & 33.05 & 33.00 & 31.65 \\
\hline Soybean oil & 33.10 & 33.05 & 33.00 & 31.65 \\
\hline Garlic powder & 0 & 20.00 & 0 & 0 \\
\hline Red onion powder & 0 & 0 & 20.00 & 0 \\
\hline Sweet red pepper powder & 0 & 0 & 0 & 20.00 \\
\hline Filler (Cellulose) & 20.00 & 0 & 0 & 0 \\
\hline Vitamin premix ${ }^{c}$ & 20.00 & 20.00 & 20.00 & 20.00 \\
\hline Mineral premix ${ }^{d}$ & 20.00 & 20.00 & 20.00 & 20.00 \\
\hline Binder (gelatin) & 20.00 & 20.00 & 20.00 & 20.00 \\
\hline Proximate composition (g kg ${ }^{-1}$ DM) & 915.10 & 908.23 & 914.00 & 912.90 \\
\hline Dry matter & 450.11 & 452.00 & 451.01 & 449.00 \\
\hline Crude protein & 99.91 & 100.03 & 10.10 & 100.05 \\
\hline Crude lipid & & & & \\
\hline
\end{tabular}

${ }^{a}$ Clopeonella meal, 21 Beiza Company, Shiraz, Iran

b Squid meal, 21 Beiza Company, Shiraz, Iran

'Vitamin premix $\mathrm{U} \mathrm{kg}^{-1}$ of premix: vitamin A, 5,000,000 IU; vitamin D3, 500,000 IU; vitamin E, 30000 $\mathrm{mg}$; vitamin $\mathrm{K} 3,1500 \mathrm{mg}$; vitamin $\mathrm{B} 1,6000 \mathrm{mg}$; vitamin B2, 24,000 mg; vitamin B5, 52,000 mg; vitamin B6, 18,000 mg; vitamin B12, 60,000 mg; Folic acid, 3000 mg; nicotinamide 180,000 mg; ascorbic acids (stay-C) $30000 \mathrm{mg}$, antioxidant, $500 \mathrm{mg}$ career up to $1 \mathrm{~kg}$, Damloran pharmaceutical Company, Broujerd, Iran.

${ }^{\mathrm{d}}$ Mineral premix mg kg${ }^{-1}$ of premix: copper, $3000 \mathrm{mg}$; zinc, $15,000 \mathrm{mg}$; manganese, 20,000 mg; Iron, 10,000 mg; potassium iodate, 300 mg; cobalt, 50 mg; selenium, 50 mg; choline chloride; $150000 \mathrm{mg}$ career up to $1 \mathrm{~kg}$, Microvit, Razak laboratories, Tehran, Iran. 


\begin{tabular}{|c|c|c|c|c|}
\hline Ingredients & Control & Garlic & Red onion & Sweet red pepper \\
\hline Crude energy ( $\left.\mathrm{kcal} \mathrm{g}^{-1}\right)$ & 5.00 & 5.09 & 5.10 & 5.07 \\
\hline \multicolumn{5}{|c|}{ a Clopeonella meal, 21 Beiza Company, Shiraz, Iran } \\
\hline \multicolumn{5}{|c|}{ b Squid meal, 21 Beiza Company, Shiraz, Iran } \\
\hline \multicolumn{5}{|c|}{ 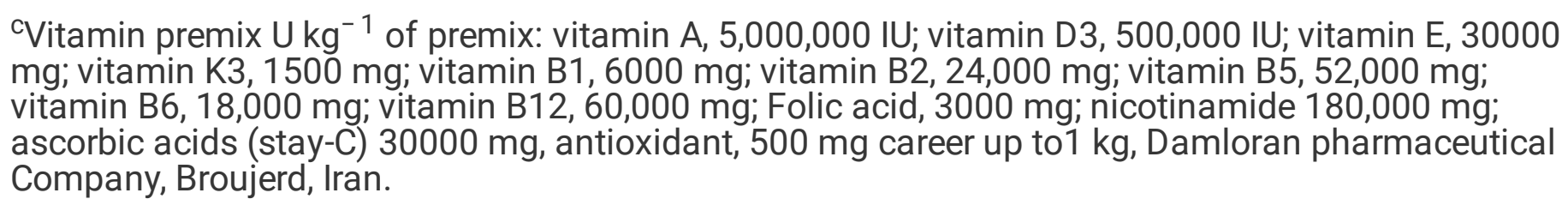 } \\
\hline \multicolumn{5}{|c|}{$\begin{array}{l}\text { dMineral premix mg kg }{ }^{-1} \text { of premix: copper, } 3000 \mathrm{mg} \text {; zinc, } 15,000 \mathrm{mg} \text {; manganese, } 20,000 \mathrm{mg} \text {; Iron, } \\
10,000 \mathrm{mg} \text {; potassium iodate, } 300 \mathrm{mg} \text {; cobalt, } 50 \mathrm{mg} \text {; selenium, } 50 \mathrm{mg} \text {; choline chloride; } 150000 \mathrm{mg} \\
\text { career up to } 1 \mathrm{~kg} \text {, Microvit, Razak laboratories, Tehran, Iran. }\end{array}$} \\
\hline
\end{tabular}

Weight gain percentage $($ WG \%) = (last fish weight $\mathrm{g}$-early fish weight $\mathrm{g}$ ) / early fish weigh $\mathrm{g} \times 100$, Specific growth rate $\left(S G R \%\right.$ day $\left.^{-1}\right)=100 \times$ (Ln last fish weight $\mathrm{g}-$ Ln early fish weight $\mathrm{g}$ ) / trial days, Feed efficiency $(\mathrm{FE} \%)=$ fish mass increase $\mathrm{g} /$ feed eating $\mathrm{g}$ (dry weight) $\times 100$, and Protein efficiency ratio $(P E R)=$ fish mass increase $\mathrm{g} /$ protein eating $\mathrm{g}$

\section{Skin Mucus Immunological Indices}

Immunological parameters were assayed by obtained supernatant of skin mucus samples by centrifuging at $1500 \times \mathrm{g}$ for $10 \mathrm{~min}$ at $4^{\circ} \mathrm{C}$, after putting the anesthetized fish with clove powder $\left(5 \mathrm{mg} \mathrm{L}^{-1}\right)$ in separate plastic bags with $50 \mathrm{mM} \mathrm{NaCl}$ for 2 min from each tank. Then, the samples were kept at $-80^{\circ} \mathrm{C}$ until analyses (Motlagh et al. 2020). Protein concentration was calorimetrically assayed with a spectrophotometer at $750 \mathrm{~nm}$ (Demers and Bayne 1997). Lysozyme activity was assayed by the lysis of gram-positive bacterium Micrococcus lysodeikticus ( Sankaran and Gurnani 1972). Alternative complement (ACH50) was determined by incubating the mixed samples with red blood cells from rabbits in buffer $(\mathrm{pH}=7,0.01 \mathrm{M})$ at $20^{\circ} \mathrm{C}$ for $90 \mathrm{~min}$. After that, the samples were added to $3.15 \mathrm{ml}$ of solution of $0.85 \% \mathrm{NaCl}$. Then, the optical density of supernatant fraction samples $\left(1600 \mathrm{rpm}\right.$ for $10 \mathrm{~min}$ at $4^{\circ} \mathrm{C}$ ) was recorded at $414 \mathrm{~nm}$ (Neissi et al. 2013). Total immunoglobulin (lg) in mucus samples was determined with the method of Siwicki et al. (1994). Briefly, $100 \mu \mathrm{l}$ of the mucus were added to the same volume of $12 \%$ polyethylene glycol, and then the supernatant fraction samples were separated after incubating samples for $2 \mathrm{~h}$ at room temperature and centrifuging at $3000 \times \mathrm{g}$ for $15 \mathrm{~min}$. Finally, the residual protein was assayed, and it was reduced from the total mucus protein concentration.

\section{Total Carotenoids Concentration}


Total carotenoids concentrations in the skin and caudal fin of fish were determined by the method of Lee et al. (2010). So, the samples of fish skin from both lateral sides and the whole caudal fin were obtained separately. Then, $20 \mathrm{ml}$ of acetone and methanol (1:1; v:v) was used for extraction samples for $30 \mathrm{~min}$. After that, the extracts were mix with $20 \mathrm{ml}$ of petroleum ether in a separation funnel. In the following, the upper phase was separated after adding distilled water and vacuum dried at $40^{\circ} \mathrm{C}$. Finally, the absorbance of the residue in petroleum ether was read at 450 using a spectrophotometer. Total carotenoid concentrations were determined by the extinction coefficient of E1\% $1 \mathrm{~cm}=2,500$ in petroleum ether.

\section{Statistical Study}

The results were studied with one-way ANOVA. Also, Duncan's multiple range test was conducted to define significant changes among the experimental groups $(p<0.05)$. Kolmogorov-Smirnov and Levene's tests were performed to confirm the normality of data and homogeneity of variance by SPSS 26 . The results were shown as mean plus standard error (SE).

\section{Result}

The results of growth and feed indices for fish were fed with various dietary herbal additives are mentioned in Table 2. So, final weight, weight gain percentage, SGR, FE, and PER of fish were fed different herbal supplements were significantly enhanced $(P<0.05)$ compared to the control. But, they have not changed considerably among various herbal additives groups $(P>0.05)$. The survival rate of fish was not altered substantially among different trial groups $(P>0.05)$. Also, fish fed the diets supplemented with various herbal additives meals had considerably $(P<0.05$, Table 3$)$ higher total protein, lysozyme activity, ACH50, and total Ig compared to the control. So, fish were nourished with $20 \mathrm{~g} \mathrm{~kg}^{-1}$ garlic powder showed considerably $(P<0.05)$ the highest immunological indices among different groups $(P<0.05)$. 
Table 2

Growth performance and feed utilization (mean $\pm S E, n=3$ ) of male guppy fed different levels of herbal additives for 60 days.

\begin{tabular}{|lllll|}
\hline & Control & Garlic & Onion & Sweet red pepper \\
\hline Final weight $\left(\mathrm{g} \mathrm{fish}^{-1}\right)$ & $1.20 \pm 0.01^{\mathrm{a}}$ & $1.26 \pm 0.00^{\mathrm{b}}$ & $1.26 \pm 0.01^{\mathrm{b}}$ & $1.25 \pm 0.00^{\mathrm{b}}$ \\
\hline Wight gain (\%) & $87.43 \pm 1.37^{\mathrm{a}}$ & $94.70 \pm 0.89^{\mathrm{b}}$ & $95.74 \pm 1.36^{\mathrm{b}}$ & $96.26 \pm 0.90^{\mathrm{b}}$ \\
\hline SGR $\left(\%\right.$ day $\left.^{-1}\right)$ & $1.04 \pm 0.01^{\mathrm{a}}$ & $1.11 \pm 0.00^{\mathrm{b}}$ & $1.12 \pm 0.01^{\mathrm{b}}$ & $1.10 \pm 0.00^{\mathrm{b}}$ \\
\hline FE (\%) & $75.70 \pm 1.83^{\mathrm{a}}$ & $89.33 \pm 1.21^{\mathrm{b}}$ & $88.30 \pm 1.47^{\mathrm{b}}$ & $90.46 \pm 1.29^{\mathrm{b}}$ \\
\hline PER & $1.68 \pm 0.04^{\mathrm{a}}$ & $1.98 \pm 0.02^{\mathrm{b}}$ & $1.96 \pm 0.03^{\mathrm{b}}$ & $2.01 \pm 0.02^{\mathrm{b}}$ \\
\hline Survival & $100^{\mathrm{n} . \mathrm{s}}$ & 100 & 100 & 100 \\
\hline $\begin{array}{l}\text { Mean values with different superscripts in the same row are significantly different from each other. } \\
\text { Significance level is defined as P< 0.05. N.s are not significantly different from each other }(P>0.05) .\end{array}$ \\
\hline
\end{tabular}

Table 3

Mucosal immune responses (mean $\pm S E, n=3$ ) of male guppy fed different levels of herbal additives for 60 days.

\begin{tabular}{|c|c|c|c|c|}
\hline & Control & Garlic & Red onion & Sweet red Pepper \\
\hline Total protein $\left(\mathrm{mg} \mathrm{ml}^{-1}\right)$ & $3.14 \pm 0.04^{a}$ & $3.72 \pm 0.06^{b}$ & $3.64 \pm 0.03^{b}$ & $3.58 \pm 0.05^{b}$ \\
\hline $\mathrm{ACH} 50\left(\mathrm{U} \mathrm{ml} \mathrm{l}^{-1}\right)$ & $1.35 \pm 0.01^{a}$ & $1.56 \pm 0.00^{c}$ & $1.44 \pm 0.02^{b}$ & $1.41 \pm 0.00^{b}$ \\
\hline Total lg $\left(\mathrm{mg} \mathrm{ml}^{-1}\right)$ & $0.12 \pm 0.01^{a}$ & $0.32 \pm 0.02^{c}$ & $0.18 \pm 0.17^{b}$ & $0.16 \pm 0.00^{a b}$ \\
\hline Lysozyme (U ml-1) & $57.00 \pm 0.57^{a}$ & $68.00 \pm 1.15^{c}$ & $61.66 \pm 1.20^{b}$ & $60.33 \pm 0.88^{b}$ \\
\hline
\end{tabular}

Furthermore, fish fed diets containing herbal additives meals had significantly higher total carotenoids concentrations in skin and caudal fin than the control $(P<0.05$, Table 4$)$. So, the fish were nourished with $20 \mathrm{~g} \mathrm{~kg}-1$ sweet red pepper showed significantly $(P<0.05)$ the highest total carotenoid content in skin and caudal fin of fish among different groups. 
Table 4

Total carotenoid content (mean $\pm S E, n=3$ ) in skin and caudal fin of male guppy fish fed different levels of herbal additives for 60 days.

\begin{tabular}{|lcccc|}
\hline & Control & Garlic & Red onion & Sweet red Pepper \\
\hline Lateral skin body $\left(\mu \mathrm{g} \mathrm{g}^{-1}\right)$ & $4.72 \pm 0.006^{\mathrm{a}}$ & $5.75 \pm 0.025^{\mathrm{b}}$ & $7.31 \pm 0.005^{\mathrm{c}}$ & $8.26 \pm 0.003^{\mathrm{d}}$ \\
\hline Caudal fin $\left(\mu \mathrm{g} \mathrm{g}^{-1}\right)$ & $5.09 \pm 0.00^{\mathrm{a}}$ & $6.49 \pm 0.003^{\mathrm{b}}$ & $8.21 \pm 0.003^{\mathrm{d}}$ & $10.10 \pm 0.005^{\mathrm{c}}$ \\
\hline $\begin{array}{l}\text { Mean values with different superscripts in the same row are significantly different from each other. } \\
\text { Significance level is defined as P<0.05. }\end{array}$ & & \\
\hline
\end{tabular}

\section{Discussion}

The results of growth and feed indices for fish indicated significant enhancement with different dietary herbal additives. In connection with garlic, the positive effects were reported for other fish species. Briefly, for African catfish, Clarias gariepinus (Agbebi et al. 2013); rainbow trout, Oncorhynchus mykiss (Gabor et al. 2012, Nya and Austin 2009); Swordtail, Xiphophorus helleri (Kalyankar et al. 2013), and Nile tilapia, Oreochromis niloticus (Aly and Mohamed 2010).

Allicin, as a crucial part of garlic improves gastrointestinal motility and stimulates the digestive enzymes to increase digestion and nutrient absorption in the aquatic organisms (Lin et al. 2006) and advanced vertebrates (Sharathchandra et al. 1995). Also, it is found that the activity of digestive enzymes is increased by dietary garlic through enhanced secretion of bile acids (Platel et al. 2002). Moreover, Esmaeili et al. (2017) reported that the dietary garlic improves the function of the digestive organs of rainbow trout with antioxidant activity. In addition, it was reported that allicin induces enhance digestion by improving intestinal flora with increasing valuable bacteria, such as Lactobacillus, thereby enhancing the use of energy and improving growth (Lee and Gao 2012). Also, Tang et al. (1997) stated that allicin could inhibit the decomposing consequence of thiaminase, guaranteeing the supplication of vitamin B1, and improved growth in fish. Finally, it was noted that garlic stimulates protein synthesis with the absorption of free amino acids from white muscle (Al-salahy 2002).

Furthermore, dietary onions were known as feed attractant and enhance fish growth (Lee and Cho 2012, Akrami et al. 2015, Saleh et al. 2015). For example, it had positive effect on growth of African catfish juveniles, C. gariepinus (Bello et al. 2012a, b), brown-marbled grouper, Epinephelus fuscoguttatus (ApinesAmar et al. 2012), beluga, Huso huso (Akrami et al. 2015), sea bass, Dicentrarcus labrax (Saleh et al. 2015), and juvenile narrow-clawed crayfish, Astacus leptodacty/us Eschscholtz, 1823 (Safari and Paolucci 2016).

The mode of action for onion on fish and crustacean species is still little explained (Akrami et al. 2015, Lee and Cho 2012, Saleh et al. 2015). But, it seems that onions, because of nutrients, can induce better performance of aquatic organisms. Also, onions have effective nutrients such as moderate quantities of protein, fat, fiber, and suitable quantities of calcium, phosphorous, potassium, vitamin C, and B6 (Mitra et 
al. 2012). Furthermore, quercetin from onions can be considered as growth promoters (Saeed et al. 2017). On the other hand, improved secretion of digestive enzymes and decrease evacuation speed in the digestive tract were displayed in rats nourished with dietary onion spice (Platel and Srinivasan 2001). Also, some scientists reported that onion, via its high soluble fiber content like inulin and fructo oligosaccharides acts as prebiotics in the digestive tract of fish (Benkeblia and Shiomi 2006, Binaii et al. 2014, Ernst and Feldheim 2000, Gibson 1998, Safari et al. 2014c, Mousavi et al. 2016) that consequently enhances growth, nutrient utilization, and host health (Nakano 2007, Ye et al. 2011).

Moreover, fish fed dietary sweet red pepper showed enhanced growth and feeding parameters. In similarity with the result of this experiment, Kamali et al. (2019) reported the improvement in growth performance of Oscar fish, Astronotus ocellatus fed by red pepper. Also, Talebi et al. (2013) and Yanar et al. (2016) stated the increased growth performance of rainbow trout fish by hot or sweet red pepper. Yilmaz et al. (2013) reported the better growth performance of red tilapia fish, Oreochromis mossambicus fed with paprika, because of carotenoids contents. Moreover, it has been stated the developed reproductive performance of yellowtail fish, Seriola quinqueradiata with carotenoid from red pepper (Agius et al. 2001, Agius et al. 2002). In another animal group, it has been stated that the weight gain of broilers is enhanced because of capsaicin from red pepper (Galib et al. 2011). Also, peppers are the best source of essential vitamins, minerals, and other nutrients (Kim et al. 2019).

On the other hand, it should be noticed, the reported results of some studies for fish performance with the same used herbal additives are not the same as the results of the current research. Briefly, lee and Cho (2012) reported no considerable improvement in survival, mass gain, or diets efficiency of olive flounder, Paralichthys olivaceus by onion. Or, Yanar et al. (2016) reported no effect of dietary red pepper on the growth of rainbow trout. And or, Motlagh et al. (2020) reported no beneficial effects of garlic extract on the growth of fry guppy fish. This contradiction can be related to fish classes, lifecycle, feeding duration, and herbal additives kinds.

The immunological parameters significantly increased in all experimental groups that showed the highest values in fish fed with garlic at $20 \mathrm{~g} \mathrm{~kg}^{-1}$ of diet. It was showed that garlic had inhibitor activity against Gyrodactylus turnbulli as a pathogen in guppies (Fridman et al. 2014, Schelkle et al. 2013). Also, it was found that dietary garlic enhances globulin and lysozyme activity in rainbow trout and Rohu fish (Labeo rohita) (Nya and Austin 2011, Sahu et al. 2007). Furthermore, garlic can be effective in stimulating complement activity in fish (Erguig et al. 2015). In addition, Motlagh et al. (2020) reported the enhancement of skin mucus immune parameters contained lysozyme, ACH50, total Ig in female guppy fish by dietary garlic extract, which is in similarity with the result of our experiment.

Furthermore, Younes et al. (2021) reported the increased innate immune response, antioxidative activities, and immune gene expressions in Nile tilapia by dietary onion. Lee and Cho (2012) mentioned increased lysozyme activity in Olive flounder by dietary onion. The improved immunological parameters of beluga were mentioned by Akrami et al (2015). The study of Apines-Amar et al. (2012) showed that onion had a 
beneficial effect on the innate immune reactions with resistance to Vibrio harveyi infection in brownmarbled grouper.

Generally, several phytonutrients, mostly polyphenols such as flavonoids and sulfur-containing compounds, have been defined in onion and garlic by scientists (Mitra et al. 2012). In this regard, allicin from garlic has the thiosulfinate efficient group with high immunological and antioxidant activities (Wang et al. 2018). In addition, the cysteine sulphoxide (CSO) with S-propenyl-CSO is the crucial S group of the onion, which has beneficial effects on the immunity system of fish (Amar and Faisan 2011).

It was reported that supplementing the diet with red pepper powder enhanced the immune system of rainbow trout fry (Mehregan et al. 2020). Also, Yigit et al. (2019) reported antimicrobial effects of red pepper in yellowtail cichlid (Pseudotropheus acei). So, phytochemicals nutrients of peppers such as carotenoids, capsaicinoids, flavonoids, ascorbic acid, and tocopherols are induced to improve the health status of fish (Mehregan et al. 2020).

The highest carotenoid concentration was observed in fish were fed with $20 \mathrm{~g} \mathrm{~kg}-1$ sweet red pepper. Yanar et al. (2016) reported the increasing effects of hot and sweet red pepper as a feed additive on coloration of rainbow trout fish. Yigit et al. (2019) reported increases coloration in the tail of yellowtail cichlid by red pepper. Yimaz and Ergun (2011) reported that the red pepper meal could be added to diets of blue streak hap (Labidochromis caeruleus) as natural carotenoid sources. It was reported, red pepper has reasonable quantities of total carotenoids that induced prosperous coloration in fish (Yilmaz et al. 2013). Furthermore, although it was not observed any studies for considering the effects of onion, or garlic meal on fish pigmentation, but it seems that the chemical nutrient of this herbal additive had positive effects on pigmentation. For example, red onions have anthocyanin pigments representing $10 \%$ of the total flavonoid content (Slimestad et al. 2007). Anthocyanins as natural vegetable colors result in red, blue, and purple colors to plants and some vegetables. Or, allicin from garlic is defined as an oxygenated carotenoid (Wang et al. 2018) that needs more study. Therefore, it seems that the used herbal additives in this study result in higher coloration than the control due to flavonoids and carotenoids contents.

\section{Conclusion}

Finally, it was found that the use of commonly herbal additives contained garlic, red onion, or sweet red pepper has positive effects on growth performance, immunity system, and coloration of fantail male guppies in juvenile stage. All used herbal additives, namely due to flavonoids and carotenoids, induced a positive effects on fish performance. So, the current study recommended that garlic or sweet red pepper meal added independently at amounts of $20 \mathrm{~g} \mathrm{~kg}^{-1}$ respectively for the highest immunity and coloration in male guppies.

\section{Declarations}


Acknowledgements

The authors acknowledge support from Khorramshahr University of Marine Science and Technology.

\section{Authors' contributions}

Seyd Nesa Mousavi performed the project. Hamid Mohammadiazarm designed the project and wrote the draft. Fatemeh Azakbakht helped throughout the experimental period.

All authors read and approved the final manuscript.

\section{Data availability}

The data gained during the current experiment are accessible from the corresponding author on logical request. The data are not publicly obtainable because of privacy or moral limitations.

\section{Compliance with ethical standards}

\section{Conflict of interest}

The authors state that they have no conflicts of interest.

\section{Ethics statement}

The experiment was conducted according to the prepared protocol of animal ethics in Khorramshahr University of Marine Science and Technology (IR.KMSU.REC1394.003).

\section{References}

1. Agbebi, O.T., Ogunmuyiwa T.G., and Herbert, S.M., 2013. Effect of dietary garlic source on feed utilization, growth and histopathology of the African catfish (Clarias gariepinus), Journal of Agricultural Science, 5, 26-34

2. Agius, R.V. et al., 2001. Supplementation of paprika as a carotenoid soure in soft-dry pellets for broodstok yellowtail Seriola quinqueradiata (Temminck and Schlegel), Aquaculture Research, 32 (1), 263-272

3. Agius, R.V. et al., 2002. Spawning performance of yellowtail Seriola quinqueradiata fed dry pellets containing paprika and squid meal, Fisheries Science, 68, 230-232

4. Ajiboye, O.O., and Qari, R., 2016. Short-term evaluation of graded levels of dietary garlic powder (allium sativum L.) as growth promoter on growth, survival and feed utilization of redbelly Tilapia, Tilapia zillii reared in glass aquaria tanks, International Journal of Marine Science, 6(34), 1-7

5. Akrami, R. et al., 2015. Effects of dietary onion (Allium cepa) powder on growth, innate immune response and hemato-biochemical parameters of beluga (Huso huso Linnaeus, 1754) juvenile. Fish and Shellfish Immunology, 45, 828-834 
6. Aly, S.M., and Mohamed, M.F., 2010. Echinacea purpurea and Allium sativum as immunostimulants in fish culture using Nile tilapia (Oreochromis niloticus), Journal of Animal Physiology and Animal Nutrition, 94, 31-39

7. Amar, E. C., and Faisan, J. P., 2011. Efficacy of an inactivated vaccine and nutritional additives against white spot syndrome virus (WSSV) in shrimp, Penaeus monodon, Bamidgeh, 63, 529-538

8. Apines-Amar, M.J.S. et al., 2012. Dietary onion and ginger enhance growth, hemato-immunological responses, and disease resistance in brown-arbled grouper, Epinephelus fuscoguttatus. AACL Bioflux $5,231-239$

9. AOAC 2000. Official methods of analysis of AOAC international, 17th edn. Association of Analytical Communities, Gaithersburg

10. Bello, O.S., Emikpe, B.O., and Olaifa, F.E., 2012a. The body weight changes and gut morphology of Clarias gariepinus juveniles in feeds supplemented with walnut (Tetracarpidium concphorum) leaf and onion (Allium cepa) Bulbs Resiues, International Journal of Morphology, 30, 253-257

11. Bello, O.S. et al., 2012b. The effect of walnut (Tetracarpidium conophorum) leaf and onion (Allium cepa) bulb residues on the tissue bacteriological changes of Clarias gariepinus juveniles, Bulltein of Animal Health and Production in Africa 60, 205-212

12. Benkeblia, N., 2004. Antimicrobial activity of essential oil extracts of various onions (Allium cepa) and garlic (Allium sativum), LWT-Food Science and Technology, 37, 263-268.

13. Benkeblia, N., and Shiomi, N., 2006. Hydrolysis kinetic parameters of DP 6, 7, 8 and 9-12 fructooligosaccharides (FOS) of onion bulb tissues, Effect of temperature and storage time, Journal of Agriculture and Food Chemistry, 54, 2587-2592

14. Binaii, M. et al., 2014. Biochemical and hemato-immunological parameters in juvenile beluga (Huso huso) following the diet supplemented with nettle (Urtica dioica). Fish and Shellfish Immunology, 36, 46-51

15. Coad, B.W., 2017. Review of the livebearer fishes of Iran (Family Poeciliidae). Iranian Journal of Ichthyology, 4(4), 305-330

16. Demers N.E., and Bayne C. J., 1997. The immediate effects of stress on hormones and plasma lysozyme in rainbow trout. Developmental and Comparative Immunology, 21, 363-373.

17. Ernst, M., and Feldheim, W. J., 2000. Fructans in higher plants and in human nutrition, Angewandte Botanik, 74, 5-9

18. Erguig, M. et al., 2015. The use of garlic in aquaculture, European journal of Biotechnology and Bioscience, 3, 28-33

19. Esmaeili, M., Abedian Kenari, A., and Rombenso, A. N., 2017. Effects of fish meal replacement with meat and bone meal using garlic (Allium sativum) powder on growth, feeding, digestive enzymes and apparent digestibility of nutrients and fatty acids in juvenile rainbow trout (Oncorhynchus mykiss Walbaum, 1792), Aquaculture Nutrition, 23(6), 1225-1234

20. FAO., 2019. The ornamental fish trade - globefish research programme - volume $102 \mathrm{GLOBEFISH}$ food and agriculture organization of the united nations (n.d.), http://www.fao.org/in- 
action/globefish/publications/details-publication/en/c/347680

21. Foysal, M.J. et al., 2019. Dietary supplementation of garlic (Allium sativum) modulates gut microbiota and health status of tilapia (Oreochromis niloticus) against Streptococcus iniae infection, Aquaculture Research, 50 2107-2116

22. Fridman, S. Sinai, T., and Zilberg, D., 2014. Efficacy of garlic based treatments against monogenean parasites infecting the guppy (Poecilia reticulata Peters), Veterinary Parasitology, 203, 51-58

23. Gabor, E.F., Sara, A., and Barbu, A., 2010. The Effects of some phytoadditives on growth, health and meat quality on different species of fish, Journal of Animal Science and Biotechnology, 43 (1), 61 65

24. Gabor, E.F. et al., 2012. The effect of phytoadditive combination and growth performances and meat quality in rainbow trout (Oncorhychus mykiss), Journal of Animal Science and Biotechnology, 45, 43-47.

25. Galib, A.M., Mamdooh, A.M., and Saba, J.A., 2011. The effects of using hot red pepper as a diet supplement on some performance traits in broiler, Pakistan Journal of Nutrition, 10 (9), 842-845.

26. Gibson, G. R., 1998. Dietary modulation of the human gut microflora using prebiotics. British Journal of Nutrition, 80, 209-212.

27. Guo, J.J. et al., 2015. The effects of garlic supplemented diets on antibacterial activities against Photobacterium damselae subsp. piscicida and Streptococcus iniae and on growth in Cobia, Rachycentron canadum, Aquaculture, 435, 111-115.

28. Kalyankar, A.D. et al., 2013. Effect of garlic (Allium Sativum) against Aeromonas Hydrophila and health management of Swordtail, Xiphophorus Helleri A.D. Journal of environmental science and sustainability, 1, 41-48.

29. Kamali, M., et al. 2019. Effect of red pepper (Capsicum annuum) and ginger (Zingiber officinale) on growth and nutrition performance, survival rate and body composition of Astronotus ocellatus, Journal of Aquaculture Development, 12(4), 107-120

30. Kim, E. H. et al., 2019.Comparison of the nutrient composition and statistical profile in red pepper fruits (Capsicums annuum L.) based on genetic and environmental factors, Applied Biological Chemistry, $62,48,1-13$

31. Lee, S. M., and Cho, S.H., 2012. Onion Powder in the Diet of the Olive Flounder, Paralichthys olivaceus: Effects on the Growth, Body Composition, and Lysozyme Activity, Journal of the World Aquaculture Society, 43(1), 30-38

32. Lee, C. R., Pham, M. A., and Lee, S. M., 2010. Effects of dietary paprika and lipid levels on growth and skin pigmentation of Pale Chub (Zacco platypus), Asian-Australasian Journal of Animal Sciences, 23(6), 724-732

33. Lee, J.Y., and Gao, Y., 2012. Review of the Application of Garlic, Allium sativum, in Aquaculture, Journal of the World Aquaculture Society, 43(2), 446-454

34. Lin, $\mathrm{H}$, Z. et al., 2006. Effect of dietary traditional Chinese medicines on apparent digestibility coefficients of nutrients for white shrimp Litopenaeus vannamei, Boone. Aquaculture, 253(1-4), 
495-501

35. Luo, Q.H. et al., 2008. Effect of Eucommia ulmoides and garlic preparations on performance and flesh quality of grass carp Ctenopharyngodon idellus, Water Conservancy Related Fisheries, 28, 6971

36. Mehregan, M.S. et al. 2020. Effect of dietary supplementation of red chili pepper (Capsicum annuum) powder on growth parameters, survival rate, hematological indices and some immunity responses of rainbow trout (Oncorhynchus mykiss) fry, Iranian Scientific Fisheries Journal, 29 (1), $131-140$

37. Metwally, M.A.A., 2009. Effects of garlic (Allium sativum) on some antioxidant activities in tilapia nilotica (Oreochromis niloticus), World Journal of Fish and Marine Science, 1, 56-64.

38. Mitra, J., Shrivastava, S. L., and Rao, P. S., 2012. Onion dehydration: a review, Journal of Food Science and Technology, 49(3), 267-277

39. Mohammadiazarm, H. et al., 2021. Effects of spirulina powder (Spirulina platensis) as a dietary additive on Oscar fish, Astronotus ocellatus: Assessing growth performance, body composition, digestive enzyme activity, immune-biochemical parameters, blood indices and total pigmentation, Aquaculture nutrition, 27, 252-260.

40. Motlagh, H.A. et al., 2020. Non-specific immunity promotion in response to garlic extract supplemented diets in female Guppy (Poecilia reticulata), Fish and Shellfish Immunology, 97, 96-99

41. Mousavi, E. et al., 2016. Effects of inulin, savory and onion powders in diet of juveniles carp Cyprinus Carpio (Linnaeus 1758) on gut micro flora, immune response and blood biochemical parameters, Turkish Journal of Fisheries and Aquatic Sciences, 16, 831-838.

42. Nakano, T. 2007. Microorganisms. In H. Nakagawa, Sato, M., and Gatlin, D. M., III (Eds.), Dietary supplements for the health and quality of cultured fish (pp. 86-109). USA: CAB International.

43. Neissi, A. et al., 2013. The effect of Pediococcus acidilactici bacteria used as probiotic supplement on the growth and non-specific immune responses of green terror, Aequidens rivulatus, Fish and Shellfish Immunology, 35 1976-1980.

44. Nya, E.J., and Austin, B., 2009. Use of garlic, Allium sativum, to control Aeromonas hydrophila infection in rainbow trout, Oncorhynchus mykiss (Walbaum), Journal of Fish Diseases, 31, 963-970

45. Nya, E.J., and Austin, B., 2011. Development of immunity in rainbow trout (Oncorhynchus mykiss, Walbaum) to Aeromonas hydrophila after the dietary application of garlic, Fish and Shellfish Immunology, 30, 845-850

46. Platel, K. et al., 2002. Digestive stimulant action of three Indian spice mixes in experimental rats, Food/Nahrung, 46(6), 394-398

47. Platel, K. and Srinivasan, K., 2001. Studies on the influence of dietary spices on food transit time in experimental rats, Nutrition Research, 21, 1309-1314

48. Ramos F.A. et al., 2006. Antibacterial and antioxidant activities of quercetin oxidation products from yellow onion (Allium cepa) skin, Journal of Agriculture and Food Chemistry, 54, 3551-3557 
49. Saleh, N. E., Michael, F. R., and Toutou, M. M., 2015. Evaluation of garlic and onion powder as phytoadditives in the diet of sea bass (Dicentrarcus labrax), The Egyptian Journal of Aquatic Research, 41, 211-217.

50. Al-Salahy, M.B., 2002. Some physiological studies on the effect of onion and garlic juices on the fish, Clarias lazera, Fish Physiology and Biochemistry, 27, 129-142

51. Saeed, M. et al., 2017. Quercetin: Nutritional and beneficial effects in poultry, World's Poultry Science Journal, $73,1-10$

52. Sahu, S. et al., 2007. Effect of Allium sativum on the immunity and survival of Labeo rohita infected with Aeromonas hydrophila, Journal of Applied Ichthyology, 23(1), 80-86

53. Safari, O. et al., 2014c. Single or combined effects of fructo-and mannan oligosaccharide supplements on the growth performance, nutrient digestibility, immune responses and stress resistance of juvenile narrow clawed crayfish, Astacus leptodactylus leptodactylus Eschscholtz, 1823, Aquaculture, 432, 192-203

54. Safari, O., and Paolucci, M., 2016. Effects of dietary onion (Allium cepa) powder on growth performance, hemolymph indices and fillet organoleptic properties of juvenile narrow-clawed crayfish, Astacus leptodactylus leptodactylus Eschscholtz, 1823, Aquaculture Nutrition, 1-11

55. Sankaran, K., and Gurnani, S., 1972. On the variation in the catalytic activity of lysozyme in fishes, Indian Journal of Biochemistry and Biophysics, 9, 162-165

56. Schelkle, B. Snellgrove, D., and Cable, J., 2013. In vitro and in vivo efficacy of garlic compounds against Gyrodactylus turnbulli infecting the guppy (Poecilia reticulata), Veterinary Parasitology, 198, 96-101

57. Siwicki, A.K., Anderson, D.P., and Rumsey, G.L., 1994. Dietary intake of immunostimulants by rainbow trout affects non-specific immunity and protection against furunculosis, Veterinary immunology and immunopathology, 41, 125-139

58. Slimestad, R, Fossen, T., and Vagen, I. M., 2007. Onions: A source of unique dietary flavonoids, Journal of Agricultural and Food Chemistry, 55 (25), 10067-80

59. Sharathchandra, J.N.N., Platel, K., and Srinivasan, K., 1995. Digestive enzymes of rat pancreas and small intestine in response to orally administered mint (Mentha spicata) leaf and garlic (Allium sativum) oil, Indian Journal of Pharmacology, 27, 156-160

60. Talebi, M. et al., 2013. Study on effect of red bell pepper on growth, pigmentation and blood factors of rainbow trout (Oncorhynchus mykiss), World Journal of Zoology, 8 (1), 17-23

61. Tang, X. R., Li, J. X., and Gao. B. T., 1997. Application of allithiamine in prawn feed, Feed Industry, 18, $39-40$

62. Van Hai, N., 2015.The use of medicinal plants as immunostimulants in aquaculture: a review, Aquaculture, 446, 88-96

63. Wang, X. et al., 2018. Allicin attenuates lipopolysaccharideinduced acute lung injuryin neonatal rats via the PI3K/Akt pathway Molecular medicine reports, 17, 6777-6783, 
64. Yanar M., Buyukcapar H.M., and Yanar. Y., 2016. Effects of hot and sweet red peppers (Capsicum annuum) as feed supplements on pigmentation, sensory properties and weight gain of rainbow trout (Onchorhynchus mykiss), Annals of animal science, 16(3), 825-834

65. Ye, J. D., Wang, K., and Sun, Y. Z., 2011. Single or combined effects of fructo and mannan oligosaccharide supplements and Bacillus clausii on the growth, feed utilization, body composition, digestive enzyme activity, innate immune response and lipid metabolism of the Japanese flounder Paralichthys olivaceus, Aquaculture Nutrition, 17, 902-911

66. Yilmaz, S., and Ergun, S., 2011. Effect of red pepper (Capsicum annuum) on pigmentation of blue streak hap (Labidochromis caeruleus), The Israeli Journal of Aquaculture- Bamidgeh, 1-7

67. Yilmaz, S., Ergun, S., and Soytas, N., 2013. Enhancement of growth performance and pigmentation in red Oreochromis mossambicus associated with Dietary Intake of Astaxanthin, Paprika, or Capsicum, The Israeli Journal of Aquaculture - Bamidgeh, 1-7

68. Yigit, M.O. et al., 2019. The Effects of Dietary Administration with High Level Red Pepper (Capsicum annuum) on Growth Performance, Coloration, Histology and Protection Against Aeromonas sobria in Yellow Tail Cichlid, Pseudotropheus acei, Acta Aquatica Trucica 15(3), 340-346.

69. Younes, A.M. et al., 2021. Effects of Onion (Allium cepa) in diets of Oreochromis niloticus: Growth improvement, antioxidant, anti-inflammatory and disease resistance perspectives, Aquaculture Research 52 (5), 2324-2334 